\title{
The Effect Of Accruals Quality On The Association Between Voluntary Disclosure And Information Asymmetry In Korea
}

Hoyoung Shin, Hanyang University, South Korea

Hyunmin Oh, Hanyang University, South Korea

\begin{abstract}
Using data on the firms' voluntary disclosures from the Korea Stock Exchange from 2011 to 2014, we first empirically examine the association between voluntary disclosure and information asymmetry and then investigate the extent to which this association is affected by accruals quality since Korea adopted International Financial Reporting Standards (IFRS) in 2011.

We use Comprix et al. (2011) and Shin and Park (2014)'s measures of information asymmetry. They are daily stock return volatility (VOLA) and trading volume turnover (VOL). We use the Dechow et al.'s (1995) revised Jones model and the Kothari et al.'s (2005) performance matched discretionary accrual model to measure the discretionary accruals. The absolute values of discretionay accruals are used as proxies for accruals quality. Final research samples with voluntary disclosure for this study are 1,226 (firms-years) companies.

The research findings generally support our hypotheses. First, the relation between voluntary disclosure and information asymmetry is statistically and significantly positive as we have expected. The Korean companies with high voluntary disclosure would experience higher daily stock return volatility and less trading volume, which implies that companies tend to disclose biased information to the outside, which is consistent with prior studies in Korea. Second, the accruals quality (moderating variable) on the relation between voluntary disclosure and information asymmetry is statistically and significantly negative. Thus, we can conclude that when accruals quality is high, more voluntary disclosure decreases information asymmetry. These findings imply that accruals quality works as a mechanism in reducing the negative effect of voluntary disclosure on information asymmetry after the adoption of IFRS in Korea.
\end{abstract}

The limitation of this study is such that we might not have considered other omitted variables and other proxies for the accruals quality, voluntary disclosure, and information asymmetry.

Keywords: Accruals Quality; Voluntary Disclosure; Information Asymmetry

\section{INTRODUCTION}

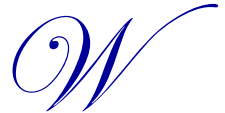

e empirically examine the effect of accruals quality on the association between voluntary disclosure (VD) and the information asymmetry since South Korea adopted the International Financial Reporting Standards (IFRS) in 2011. Korean-adopted IFRS (K-IFRS) does not provide detailed accounting guidelines on the preparation of financial statements since IFRS is principle-based rather than rule-based. Thus, it is generally anticipated that managerial discretion which causes accruals volatility to be too high or too low relative to industry norms will increase information asymmetry between managers and investors (and/or among investors). The existence of information asymmetry in the capital market could affect the efficient allocation of scarce economic resources, causing the problem of adverse selection, and potentially induce the market failure.

After the Asian financial crisis in the late 1990s, Korea revamped its financial reporting systems and introduced the fair disclosure regulations in order to improve the accounting transparency and mitigate the problem of information 
asymmetry. The disclosure requirement can work as a remedy in reducing the information asymmetry. However, investors and regulators have doubted the credibility of voluntary disclosure. To protect the investors and enhance the credibility of voluntary disclosure, the Korean government enacted a rule to incorporate voluntary disclosure into its regulation system in April, 2000. Since then, the government has further encouraged firms to expand the voluntary disclosure, hoping that it could enhance the relevance of accounting information and as a result, reduce information asymmetry in the market.

Prior studies provide conflicting results on the role of voluntary disclosure on the information asymmetry in Korea. Cho and Jo (2010) prove that the quarterly reports initiated in 2000 reduced information asymmetry in Korea. However, Sohn et al. (2008) report that the frequency of the voluntary disclosure increased the analysts' earnings forecasts error and bias. Shin and Lee (2014) also argue that voluntary disclosure increased the information asymmetry in Korea. These results indicate that unlike the government's intention, it is possible for firms to provide favorable and biased information through the system, losing the credibility of information. Thus, whether a positive relation between voluntary disclosure and the information asymmetry still holds since Korea adopted IFRS in 2011 is an empirical question to be tested. Accordingly, following Sohn et al. (2008) and Shin and Lee (2014), we hypothesize that Korean firms with high voluntary disclosure would experience higher daily stock return volatility and less trading volume turnover.

A firm's accruals is defined as the difference between reported earnings and cash flows from operations. High accruals quality mitigates information risks of the firm about future cash flows and earnings by reducing information asymmetry between firms and the market participants. Market participants will ask for an additional premium as a consideration for poor accruals quality, which means higher information risk. It is expected that because accounting accruals are a comprehensive measure of all accounting choices made by management, they are likely to capture earnings management (Watts and Zimmerman 1990). The availability of discretionary reporting choices may erode the information content of earnings (Cormier and Magnan 2002; Oh et al. 2016). Accordingly, we expect that the better accruals quality firms have, the less information asymmetry. Cho and Jo (2010) investigate the effect of accruals quality on the firms' information asymmetry and find that firms with less volatility of accruals enjoy less daily stock return volatility and higher trading volume turnover. However, the effect of accruals quality on the relations between voluntary disclosure and information asymmetry has not yet been studied in Korea. Thus, we test whether accruals quality mitigates the relation between voluntary disclosure and information asymmetry.

The research findings generally support our hypotheses. First, the relation between voluntary disclosure and information asymmetry is statistically and significantly positive. Second, the interaction variable on the relation between voluntary disclosure and information asymmetry is statistically and significantly negative. Thus, we can conclude that the effect of voluntary disclosure and accruals quality on information asymmetry decreases for firms with high accruals quality. When accruals quality is high, more voluntary disclosure decreases information asymmetry. These findings imply that accruals quality works as a mechanism in reducing the negative effect of voluntary disclosure on information asymmetry after the adoption of IFRS in Korea by providing firm's information to the market. This study provides evidence that high accruals quality, when combined with voluntary disclosure, reduces information asymmetry and thus contributes to the enhancement and usefulness of the voluntary disclosure information.

The rest of the paper is organized as follows. Section II reviews prior literature and develops the research hypothesis. Section III presents the research design. Section IV reports the empirical results. Section V sets forth the conclusion.

\section{BACKGROUND AND HYPOTHESES DEVELOPMENT}

\subsection{Voluntary Disclosure and Information Asymmetry}

Generally voluntary disclosures are expected to decrease information between managers and investor (and / or among investors) (Francis et al. 2008; Sohn et al. 2008). However, investors and regulators have a question about the reliability of voluntary disclosures. The Korean government enacted a rule to incorporate voluntary disclosures, into a part of its regulation system in March, 2000, as a device of timely disclosures ruled by Financial Supervisory Service (FSS) and Korea Exchange (KRX), and the government has been encourage firms to voluntary disclosure their private 
information through its regulation system(Sohn et al. 2008). Meanwhile, a variety of prior literatures have examined the effect of voluntary disclosure introduction on information asymmetry since 2000 in Korea. But, study examined the effect voluntary disclosure on information asymmetry after adoption of K-IFRS is scare. This study investigated the effect voluntary disclosure on information asymmetry after adoption of K-IFRS.

Before adoption of K-IFRS, Prior literature shows mixed evidence on the relation between voluntary disclosure and information asymmetry. Lee and Shin (2010), unlike Francis and Nanda (2008), argue that firms with more expansive voluntary disclosure are associated with lower cost of capital when controlled for accruals quality and try to reduce the information asymmetry through expansive voluntary disclosures. However, Sohn et al. (2008) and Shin and Lee (2014) show that the frequency of the voluntary disclosure is significantly and positively related to the information asymmetry. Thus, following Sohn et al. (2008) and Shin and Lee (2014), we predict that Korean firms with high voluntary disclosure would experience higher daily stock return volatility and less trading volume turnover and hypothesize as follows:

$\mathbf{H}_{1}$ : There is a positive association between voluntary disclosure and information asymmetry after adoption of KIFRS.

$\mathbf{H}_{2}$ : There is a positive association between voluntary disclosure frequency and information asymmetry after adoption of K-IFRS.

\subsection{Accruals Quality, Voluntary Disclosure, and Information Asymmetry}

Previous empirical evidence supports a negative correlation between high accruals quality (including accruals quality) and low information asymmetry. (Ecker et al. 2006; Rajgopal and Venkatachalam 2006; Cho and Jo 2010) Thus, better accruals quality firms have, the less information asymmetry. However, whether accruals quality mitigates the positive association between voluntary disclosure and information asymmetry has not yet been investigated. Thus, we hypothesize as follows:

$\mathbf{H}_{3}$ : The accruals quality has a moderating effect on the negative relationship between voluntary disclosure and information asymmetry after adoption of K-IFRS.

$\mathbf{H}_{4}$ : The accruals quality has a moderating effect on the negative relationship between voluntary disclosure frequency and information asymmetry after adoption of K-IFRS.

\section{RESEARCH DESIGN}

\subsection{Regression Models}

To test Hypothesis 1 and Hypothesis 2, we use a multivariate regression model to investigate whether the voluntary disclosure (voluntary disclosure frequency) increases information asymmetry as we have expected. The voluntary disclosure and voluntary disclosure frequency are used as proxies for the voluntary disclosure and VOLA (daily stock return volatility) and VOL (trading volume turnover) for information asymmetry for equations (1) and (2). Regression models are as follows;

$$
\begin{aligned}
V O L A_{i t}= & \beta_{0}+\beta_{1} V D_{i t}(\text { or COUNT })+\beta_{2} S I Z E_{i t}+\beta_{3} L E V_{i t}+\beta_{4} B E T A_{i t}+\beta_{5} V O L_{i t}+ \\
& \beta_{6} F O R_{i t}+\varepsilon_{i t} \\
V O L A_{i t}= & \beta_{0}+\beta_{1} V D_{i t}(\text { or COUNT })+\beta_{2} S I Z E_{i t}+\beta_{3} L E V_{i t}+\beta_{4} B E T A_{i t}+\beta_{5} V O L A_{i t}+ \\
& \beta_{6} F O R_{i t}+\varepsilon_{i t}
\end{aligned}
$$

To test Hypothesis 3 and Hypothesis 4, we use a multivariate regression model to investigate whether accruals quality has a moderating effect on the positive relationship between voluntary disclosure (or voluntary disclosure frequency) and information asymmetry. To estimate the accruals quality, We use the Dechow et al.'s (1995) modified Jones model and the Kothari et al.'s (2005) performance matched discretionary accrual model to measure the discretionary accruals. The absolute values of discretionary accruals are used as proxies for accruals quality. Regression models are as follows; 


$$
\begin{aligned}
V O L A_{i t}= & \beta_{0}+\beta_{1} V D_{i t}(\text { or COUNT })+\beta_{2} A Q_{-} D U M_{i t}+\beta_{3} V D(\text { or COUNT })_{i t} \times A Q_{-} D U M_{i t}+ \\
& \beta_{4} \text { SIZE }_{i t}+\beta_{5} L E V_{i t}+\beta_{6} \text { BETA }_{i t}+\beta_{7} V O L_{i t}+\beta_{8} F O R_{i t}+\varepsilon_{i t} \\
V O L_{i t}= & \beta_{0}+\beta_{1} V D_{i t}(\text { or COUNT })+\beta_{2} A Q_{D U M_{i t}}+\beta_{3} V D(\text { or COUNT })_{i t} \times A Q_{D U M_{i t}}+ \\
& \beta_{4} \text { SIZE }_{i t}+\beta_{5} L E V_{i t}+\beta_{6} \text { BETA }_{i t}+\beta_{7} V O L A_{i t}+\beta_{8} F O R_{i t}+\varepsilon_{i t}
\end{aligned}
$$

\section{Variable Definitions:}

VOLA $_{\text {it }}$ : the standard deviation of daily stock returns for firm i over the one-year period from the second quarter of year $\mathrm{t}$ to the first quarter of year $\mathrm{t}+1$;

$\mathrm{VOL}_{\mathrm{it}}$ : the mean daily trading volume scaled by shares outstanding for firm i over the one-year period from the second quarter of year $t$ to the first quarter of year $t+1$;

$\mathrm{VD}_{\mathrm{it}}$ : an indicator variable equal to one if the firm issues at least one voluntary disclosure in a given year, 0 otherwise;

$\mathrm{COUNT}_{\text {it }}$ : voluntary disclosure frequency;

AQ_DUM $\mathrm{it}_{\mathrm{it}}$ : accruals quality indicator variable;

$\mathrm{AQ}_{1} \mathrm{DUM}_{\mathrm{it}}$ : an indicator variable equals to 1 if the firm has less than the absolute values of residuals according to the modified Jones model (1995), 0 otherwise ;

$\mathrm{AQ}_{2} \mathrm{DUM}_{\mathrm{it}}$ : an indicator variable equals to 1 if the firm has less than the absolute values of residuals according to the performance matched Kothari model (2005), 0 otherwise ;

$\mathrm{VD}_{\mathrm{it}}$ *AQ_DUM $\mathrm{it}_{\mathrm{t}}$ : interaction variable between voluntary disclosure indicator variable and accruals quality indicator variable;

$\mathrm{COUNT}_{\mathrm{it}}$ *AQ_DUM $\mathrm{it}_{\mathrm{it}}$ : interaction variable between voluntary disclosure frequency variable and accruals quality indicator variable;

$\mathrm{SIZE}_{\mathrm{it}}$ : the natural log of total assets for firm $\mathrm{i}$ in year $\mathrm{t}$;

$\mathrm{LEV}_{\mathrm{it}}$ : total liabilities deflated by total assets;

BETA $_{i t}$ : systematic risk, estimated value using monthly stock returns for firm i over the five years period from year $\mathrm{t}$ to year $\mathrm{t}-$ 4

$\mathrm{FOR}_{\mathrm{it}}$ : foreign ownership;

$\varepsilon_{i t}=$ residuals, the estimated error in the model

VD is an indicator variable equal to one if the firm issues at least one voluntary disclosure in a given year, 0 otherwise. COUNT presents voluntary disclosure frequency for firms with voluntary disclosure data. We predict a positive $(+)$ association between VD ( or COUNT ) and information asymmetry. AQ_DUM is an indicator variable equal to 1 if the firm has less than the absolute values of residuals, 0 otherwise. We predict a negative (-) association between AQ_DUM and information asymmetry. Control variables are SIZE, LEV, BETA, FOR.

SIZE is the natural log of total assets for firm i in year t. Size is added to control firm size effect and omitted variables effect (Francis et al. 2005). We predict a negative (-) association between SIZE and information asymmetry because information environment for firms with bigger size is rich.

LEV is total liabilities deflated by total assets. If LEV is high, firms will be reluctant to disclose information. We predict a positive $(+)$ association between LEV and information asymmetry (Cho and Jo 2010). 
BETA is systematic risk, estimated by using monthly stock returns for firm i over the five years period from year $\mathrm{t}$ to year $\mathrm{t}-4$. Firms with bigger systematic risk will be reluctant to disclose information. Therefore, We predict a positive $(+)$ association between BETA and information asymmetry (Botosan 1997).

FOR is foreign ownership. Prior literature indicates that foreign investors have played an important role in improving the information asymmetry (Ahn et al. 2005; Cho and Jo 2010). We predict a negative (-) association between FOR and information asymmetry.

\subsection{Measure of Variables}

\subsubsection{Information Asymmetry}

A dependent variable is the information asymmetry. We use VOLA and VOL as proxies for information asymmetry (Lang and Lundholm 1993; Leuz and Verrecchia 2000; Shin and Park 2014). VOLA means standard deviation of daily stock returns for firm $i$ over the one-year period from the second quarter of year $t$ to the first quarter of year $t+1$. Higher standard deviation of daily stock returns shows that information asymmetry between investors and firms is bigger (Cho and Jo 2010). Thus, we expect a positive association with voluntary disclosure.

The VOL means the mean daily trading volume scaled by shares outstanding for firm i over the one-year period from the second quarter of year $t$ to the first quarter of year $t+1$. Trading volume turnover presents the market liquidity of stocks for firms. Market liquidity indicates the intention to make a deal to the capital market, where higher daily trading volume shows that there are many investors who want to trade stocks in the capital market (Glosten and Milgrom 1985; Cho and Jo 2010). Thus, the intention to trade stocks and information asymmetry have an inverse relationship.

\subsubsection{Accruals Quality}

\subsubsection{Dechow et al. (1995)'s Modified Jones Model}

The first measure is discretionary accruals as developed by Dechow et al.'s (1995) modified Jones model. Specifically, we estimate the following model by year and for each industry that has at least 10 observations: We use the absolute values of discretionary accruals $(|\mathrm{AM}|)$ as a proxy for accruals quality. Thus, higher values represent lower accruals quality.

$$
\begin{aligned}
& \frac{\mathrm{TAC}_{\mathrm{it}}}{\mathrm{A}_{\mathrm{it}-1}}=\mathrm{a}_{0}\left(\frac{1}{\mathrm{~A}_{\mathrm{it}-1}}\right)+\mathrm{a}_{1}\left(\frac{\Delta \mathrm{REV}_{\mathrm{it}}-\Delta \mathrm{AR}_{\mathrm{it}}}{\mathrm{A}_{\mathrm{it}-1}}\right)+\mathrm{a}_{2}\left(\frac{\mathrm{PPE}_{\mathrm{it}}}{\mathrm{A}_{\mathrm{it}-1}}\right)+\varepsilon_{i t} \\
& |\mathrm{AM}|=\left|\left(\frac{\mathrm{TAC}_{\mathrm{it}}}{\mathrm{A}_{\mathrm{it}-1}}\right)-\left[\hat{\mathrm{a}}_{0}\left(\frac{1}{\mathrm{~A}_{\mathrm{it}-1}}\right)+\hat{\mathrm{a}}_{1}\left(\frac{\Delta \mathrm{REV}_{\mathrm{it}}-\Delta \mathrm{AR}_{\mathrm{it}}}{\mathrm{A}_{\mathrm{it}-1}}\right)+\hat{\mathrm{a}}_{2}\left(\frac{\mathrm{PPE}_{\mathrm{it}}}{\mathrm{A}_{\mathrm{it}-1}}\right)\right]\right|
\end{aligned}
$$

In this model,

$|\mathrm{AM}|$ : absolute values of residuals measured by Dechow et al.'s (1995) revised Jones model;

$\mathrm{TAC}_{\mathrm{it}}$ : total accruals, measured as the change in non-cash current assets minus the change in current non-interest-bearing liabilities, minus depreciation and amortization expenses for firm $i$ at year $t$;

$\Delta \mathrm{REV}_{\mathrm{it}}$ : changes in sales revenue for firm $\mathrm{i}$ in year $\mathrm{t}$;

$\Delta \mathrm{AR}_{\mathrm{it}}$ : changes in receivables for firm $\mathrm{i}$ in year $\mathrm{t}$;

$\mathrm{PPE}_{\mathrm{it}}$ : gross sum of property, plant, and equipment for firm i in year $\mathrm{t}$;

$A_{i t-1}$ : total assets for firm $i$ in year $t-1$; 


\subsubsection{Kothari et al. (2005) model}

The second measure is performance-adjusted discretionary accruals as developed by Kothari et al. (2005). Specifically, we estimate the following model by year and for each industry that has at least 10 observations: We use the absolute values of discretionary accruals as a proxy for accruals quality (|AM_ROA $\mid)$. Thus, greater the absolute size of the residual (|AM_ROA $\mid$ ), greater the discretionary accruals, the lower the accruals quality.

$$
\begin{aligned}
& \frac{\mathrm{TAC}_{\text {it }}}{\mathrm{A}_{\mathrm{it}-1}}=\mathrm{a}_{0}\left(\frac{1}{\mathrm{~A}_{\mathrm{it}-1}}\right)+\mathrm{a}_{1}\left(\frac{\Delta \mathrm{REV}_{\mathrm{it}}-\Delta \mathrm{AR}_{\mathrm{it}}}{\mathrm{A}_{\mathrm{it}-1}}\right)+\mathrm{a}_{2}\left(\frac{\mathrm{PPE}_{\mathrm{it}}}{\mathrm{A}_{\mathrm{it}-1}}\right)+\mathrm{a}_{3} \mathrm{ROA}_{\mathrm{it}}+\varepsilon_{i t} \\
& \left|\mathrm{AM}_{-} \mathrm{ROA}\right|=\left|\left(\frac{\mathrm{TAC}}{\mathrm{A}_{\mathrm{it}}-1}\right)-\left[\hat{\mathrm{a}}_{0}\left(\frac{1}{\mathrm{~A}_{\mathrm{it}-1}}\right)+\hat{\mathrm{a}}_{1}\left(\frac{\Delta \mathrm{REV}_{\mathrm{it}}-\Delta \mathrm{AR}_{\mathrm{it}}}{\mathrm{A}_{\mathrm{it}-1}}\right)+\hat{\mathrm{a}}_{2}\left(\frac{\mathrm{PPE}_{\mathrm{it}}}{\mathrm{A}_{\mathrm{it}-1}}\right)++\hat{\mathrm{a}}_{3}\left(\mathrm{ROA}_{\mathrm{it}}\right)\right]\right|
\end{aligned}
$$

In this model,

$\mid$ AM_ROA|: absolute values of residuals measured by Kothari et al. (2005);

$\mathrm{TAC}_{\mathrm{it}}$ : total accruals, measured as the change in non-cash current assets minus the change in current non-interest-bearing liabilities, minus depreciation and amortization expenses for firm i at year $t$;

$\Delta \mathrm{REV}_{\mathrm{it}}$ : changes in sales revenue for firm $\mathrm{i}$ in year $\mathrm{t}$;

$\Delta \mathrm{AR}_{\mathrm{it}}$ : changes in receivables for firm $\mathrm{i}$ in year $\mathrm{t}$;

$\mathrm{PPE}_{\mathrm{it}}$ : gross sum of property, plant, and equipment for firm $\mathrm{i}$ in year $\mathrm{t}$;

$\mathrm{ROA}_{\mathrm{it}}$ : pretax income for firm $\mathrm{i}$ in year $\mathrm{t}$ scaled by prior year total assets;

$A_{i t-1}$ : total assets for firm $i$ in year $t-1$;

\subsection{Sample Selection}

We employ the data collected from 2011 to 2014 from the Korean stock market. The sample selection process is summarized in Table 1. We first eliminate the quoted non-financial December firms for which financial and stock data cannot be collected from FN-Guide. Those companies whose year-ends are not on December 31 are excluded because of data homogeneity. Financial firms are also eliminated since the nature of the business is different from our sample. The final sample for model 1 and model 2 is 2,584 firm-year observations. Additionally, we exclude firms for which voluntary disclosure data cannot be collected. The final sample for the Model (3) and Model (4) consists of 1,226 firm-year observations. We winsorize each of the continuous variables at the 1st and 99th percentiles to minimize the effect of outliers. Panel A of Table 2 shows the distribution across fiscal years in our sample. Panel B of Table 2 shows the distribution by industry in our sample. Panel C of Table 2 show the items of voluntary disclosure.

Table 1. Sample selection

\begin{tabular}{l|c}
\hline \multicolumn{1}{c}{ Criteria } & Firm-Year Observations \\
\hline Quoted non-financial December 31 firms for fiscal years 2011-2014 & 2,627 \\
\hline (less) Firms for which financial and stock data cannot be collected from FN-Guide & $(43)$ \\
\hline Total (sample for Hypothesis 1, 2) & 2,584 \\
\hline (less) Firms for which voluntary disclosure data cannot be collected & $(1,358)$ \\
\hline Total (sample for Hypothesis 3, 4) & 1,226 \\
\hline
\end{tabular}


Table 2. Distributions of voluntary disclosure over the sample period

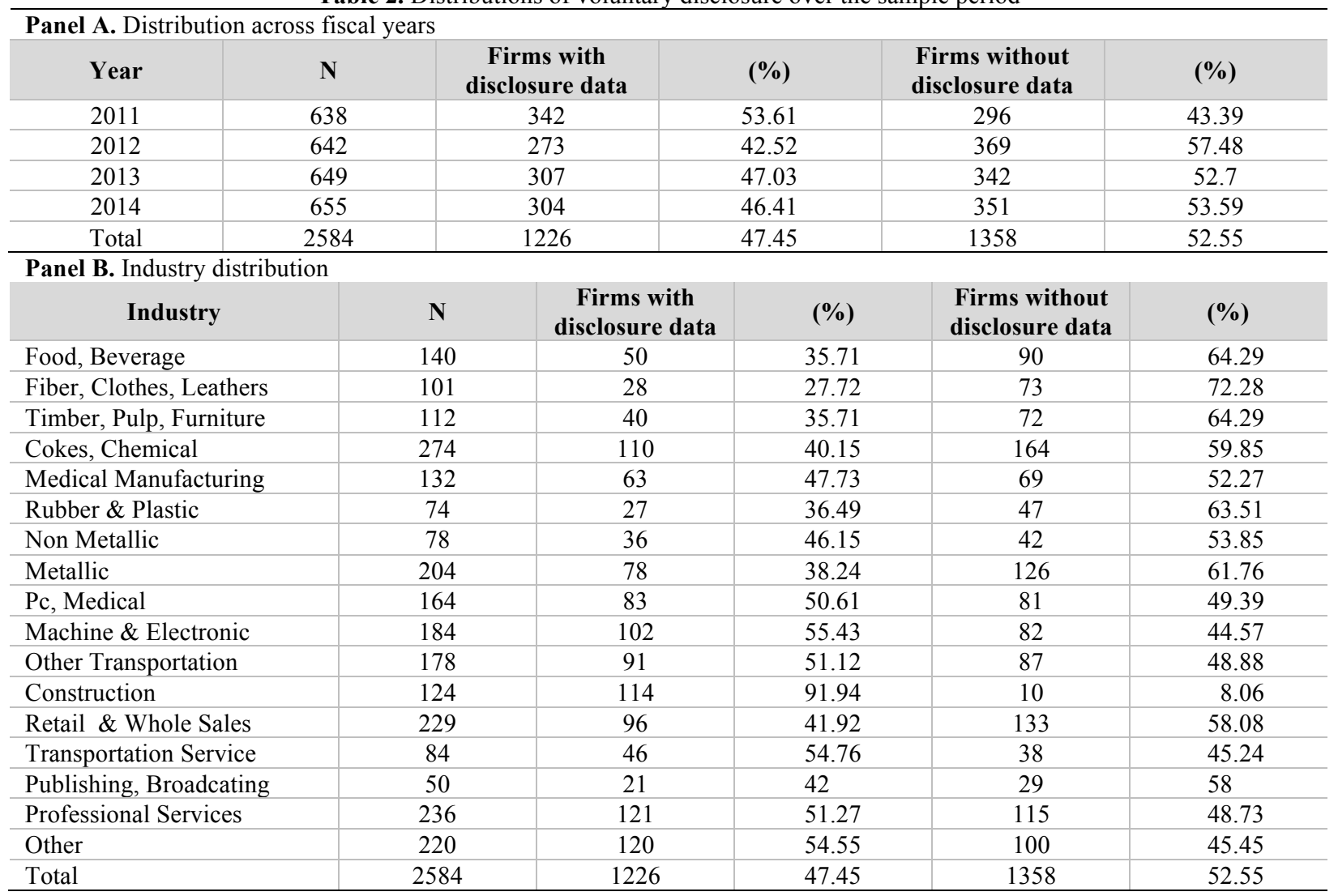

Panel C. Disclosure items

\begin{tabular}{l|c|c}
\multicolumn{1}{c|}{ Items } & N & Ratio(\%) \\
\hline Other major management issues & 2,294 & 45.8 \\
\hline Single sale and supply agreement & 776 & 15.5 \\
\hline Patent Acquisition & 499 & 10.0 \\
\hline Other corporate investment and disposal & 291 & 5.8 \\
\hline Affiliated companies change & 245 & 3.9 \\
\hline Seasoned equity offerings (seo) and Equity-related bonds & 180 & 2.9 \\
\hline Green Information Management & 147 & 1.8 \\
\hline Salse and Income structure change & 88 & 1.4 \\
\hline Greenhouse Gases and energy & 71 & 1.1 \\
\hline Tangible assets acquired / disposed of & 53 & 0.9 \\
\hline Technology Introduction & 43 & 0.8 \\
\hline Family Friendly & 39 & 0.7 \\
\hline Lawsuit & 33 & 0.6 \\
\hline Embezzlement and misappropriation & 32 & 0.6 \\
\hline Infrastructure Investment & 31 & 0.6 \\
\hline Sustainable management report & 28 & 0.5 \\
\hline Loan guarantees & 23 & 0.4 \\
\hline Single sale and supply cancellation & 18 & 0.3 \\
\hline Mutual savings bank & 15 & 0.3 \\
\hline Short-term loan & 13 & \\
\hline Pant C conting & & \\
\hline
\end{tabular}

(Panel C continued on next page) 
Panel C. continued

\begin{tabular}{|c|c|c|}
\hline the & $\mathbf{N}$ & Ratio(\%) \\
\hline Money rentals & 9 & 0.2 \\
\hline Resource Development & 9 & 0.2 \\
\hline Asset revaluation & 8 & 0.2 \\
\hline Receipt & 7 & 0.1 \\
\hline Major shareholders change & 7 & 0.1 \\
\hline Other & 51 & 1.0 \\
\hline Total & 5,010 & 100 \\
\hline
\end{tabular}

\section{EMPRICAL RESULTS}

\subsection{Descriptive Statistics}

Panel A of Table 3 presents descriptive statistics for the full sample. The mean (median) of standard deviation of daily stock returns (VOLA) is 2.617 (2.402). The mean (median) value of mean daily trading volume (VOL) is 2.179 (1.047). In Korea, $47.4 \%$ of firms listed on the KSE issue voluntary disclosure. The mean of absolute value of residuals measured by Dechow et al. (1995) is 0.054 (AQ1). The mean of absolute values of residuals measured by Kothari et al. (2005) is 0.054 (AQ2). The average size is 26.825 . The mean leverage (LEV) is $43.7 \%$. The mean BETA and foreign ownership are 0.887 and $9.486 \%$ respectively.

Panel B of Table 3 presents descriptive statistics for firms that shows the frequency of voluntary disclosures. LEV, SIZE, and BETA are normaly distributed. The mean (median) standard deviation of daily stock returns (VOLA) is 2.733 (2.513). The mean (median) value of mean daily trading volume (VOL) is 2.077 (1.127). The mean frequency of voluntary disclosure is 3.1, implying that firms issue voluntary disclosure at least 3 times a year. The mean of absolute values of residuals measured by Dechow et al. (1995) is 0.056 (AQ1) and that measured by Kothari et al. (2005) is 0.055 (AQ2). The average size is 27.196. The mean leverage (LEV) is $47.4 \%$. The mean BETA and foreign ownership are 0.974 and $11.159 \%$ respectively.

Table 3. Descriptive Statistics

\begin{tabular}{|c|c|c|c|c|c|c|c|}
\hline \multicolumn{8}{|c|}{ Panel A. Full samples $(\mathrm{N}=2,584)$} \\
\hline Variable & Mean & Std. Dev. & Min & $\begin{array}{c}\text { 25th } \\
\text { pecentile }\end{array}$ & Median & $\begin{array}{c}\text { 75th } \\
\text { pecentile }\end{array}$ & Max \\
\hline VOLA & 2.617 & 1.062 & 0.984 & 1.870 & 2.402 & 3.159 & 6.178 \\
\hline$V O L$ & 2.179 & 4.466 & 0.000 & 0.000 & 1.047 & 2.298 & 30.057 \\
\hline$V D$ & 0.474 & 0.499 & 0.000 & 0.000 & 0.000 & 1.000 & 1.000 \\
\hline$A Q 1$ & 0.054 & 0.046 & 0.000 & 0.015 & 0.038 & 0.088 & 0.134 \\
\hline$A Q 2$ & 0.054 & 0.045 & 0.000 & 0.015 & 0.040 & 0.087 & 0.130 \\
\hline SIZE & 26.825 & 1.498 & 23.914 & 25.827 & 26.607 & 27.617 & 30.996 \\
\hline$L E V$ & 0.437 & 0.212 & 0.017 & 0.271 & 0.435 & 0.586 & 0.960 \\
\hline BETA & 0.887 & 0.538 & -0.200 & 0.553 & 0.890 & 1.240 & 2.248 \\
\hline FOR & 9.486 & 13.079 & 0.000 & 0.765 & 3.581 & 13.338 & 60.095 \\
\hline \multicolumn{8}{|c|}{ Panel B. Firm samples with voluntary disclosure data $(\mathrm{N}=1,226)$} \\
\hline Variable & Mean & Std. Dev. & Min & $\begin{array}{c}\text { 25th } \\
\text { pecentile }\end{array}$ & Median & $\begin{array}{c}\text { 75th } \\
\text { pecentile }\end{array}$ & Max \\
\hline VOLA & 2.733 & 0.974 & 1.331 & 1.983 & 2.513 & 3.343 & 4.839 \\
\hline$V O L$ & 2.077 & 2.369 & 0.127 & 0.600 & 1.127 & 2.398 & 9.228 \\
\hline COUNT & 3.104 & 2.769 & 1.000 & 1.000 & 2.000 & 4.000 & 11.000 \\
\hline$A Q 1$ & 0.056 & 0.046 & 0.000 & 0.016 & 0.040 & 0.092 & 0.134 \\
\hline$A Q 2$ & 0.055 & 0.045 & 0.000 & 0.016 & 0.041 & 0.089 & 0.130 \\
\hline SIZE & 27.196 & 1.534 & 24.635 & 26.042 & 26.979 & 28.353 & 29.867 \\
\hline$L E V$ & 0.474 & 0.201 & 0.103 & 0.316 & 0.486 & 0.624 & 0.803 \\
\hline BETA & 0.974 & 0.477 & 0.176 & 0.623 & 0.971 & 1.340 & 1.795 \\
\hline FOR & 11.159 & 14.642 & 0.000 & 0.935 & 4.946 & 16.190 & 89.733 \\
\hline
\end{tabular}

Variable Definitions: 
VOLA $A_{\mathrm{it}}$ : the standard deviation of daily stock returns for firm i over the one-year period from the second quarter of year $\mathrm{t}$ to the first quarter of year $t+1$;

$\mathrm{VOL}_{\mathrm{it}}$ : the mean daily trading volume scaled by shares outstanding for firm i over the one-year period from the second quarter of year $t$ to the first quarter of year $t+1$;

$\mathrm{VD}_{\mathrm{it}}$ : an indicator variable equal to one if the firm issues at least one voluntary disclosure in a given year, 0 otherwise;

COUNT $_{\text {it: }}$ voluntary disclosure frequency;

AQ_DUM $\mathrm{it}_{\mathrm{it}}$ accruals quality indicator variable;

$\mathrm{AQ}_{1} \mathrm{DUM}_{\mathrm{it}}$ : an indicator variable equals to 1 if the firm has less than the absolute values of residuals according to the modified Jones model (1995), 0 otherwise;

$\mathrm{AQ}_{2} \mathrm{DUM}_{\mathrm{it}}$ : an indicator variable equals to 1 if the firm has less than the absolute values of residuals according to the performance matched Kothari model (2005), 0 otherwise;

$\mathrm{VD}_{\mathrm{it}}$ *AQ_DUM $\mathrm{it}_{\mathrm{t}}$ : interaction variable between voluntary disclosure indicator variable and accruals quality indicator variable;

$\mathrm{COUNT}_{\mathrm{it}}$ *AQ_DUM $\mathrm{it}_{\mathrm{it}}$ interaction variable between voluntary disclosure frequency variable and accruals quality indicator variable;

SIZE $_{\mathrm{it}}$ : the natural $\log$ of total assets for firm $\mathrm{i}$ in year $\mathrm{t}$;

$\mathrm{LEV}_{\mathrm{it}}$ : total liabilities deflated by total assets;

BETA $_{\mathrm{it}}$ : systematic risk, estimated value using monthly stock returns for firm i over the five years period from year $\mathrm{t}$ to year $\mathrm{t}$ 4

$\mathrm{FOR}_{\mathrm{it}}$ : foreign ownership;

\subsection{Correlation Analysis}

Panel A of Table 4 presents pearson correlations. VOLA is significantly and positively $(+)$ correlated with VD, LEV, and BETA. This means voluntary disclosure, higher debt ratio, and higher risk make larger the standard deviation of daily stock returns. Thus, voluntary disclosure increases information asymmetry. VD is significantly and positively $(+)$ correlated with VOL. This means voluntary disclosure makes larger the mean daily trading volume. AQ1 and AQ2 are significantly and negatively (-) correlated with VOLA and VOL. This shows that the standard deviation of daily stock returns decreases for firms with better accruals quality and the mean daily trading volume increases for firms with better accruals quality.

Panel B of Table 4 presents pearson correlations for firms with voluntary disclosure data. COUNT (voluntary disclosure frequency) is significantly and positively $(+)$ correlated with VOLA. This means voluntary disclosure frequency makes larger the standard deviation of daily stock returns. Thus, voluntary disclosure frequency increases information asymmetry. COUNT is not significantly and positively $(+)$ correlated with VOL. AQ1 and AQ2 are significantly and negatively (-) correlated with VOLA and VOL. This explains that the standard deviation of daily stock returns decreases for firms with higher accruals quality, the mean daily trading volume increases for firms with higher accruals quality. 
Table 4. Pearson Correlations

\begin{tabular}{|c|c|c|c|c|c|c|c|c|}
\hline \multicolumn{9}{|c|}{ Panel A. Full samples $(\mathrm{N}=2,584)$} \\
\hline & $V O L A$ & $V O L$ & $V D$ & $A Q 1$ & $A Q 2$ & SIZE & $L E V$ & BETA \\
\hline$V O L$ & $0.732^{* * *}$ & & & & & & & \\
\hline$V D$ & $0.131^{* * *}$ & $0.047^{* *}$ & & & & & & \\
\hline$A Q 1$ & $-0.117^{* * *}$ & $-0.099^{* * *}$ & -0.029 & & & & & \\
\hline$A Q 2$ & $-0.093^{* * *}$ & $-0.060^{* * *}$ & -0.031 & $0.821^{* * *}$ & & & & \\
\hline SIZE & $-0.287^{* * *}$ & $-0.330^{* * *}$ & $0.263^{* * *}$ & $0.153^{* * *}$ & $0.131^{* * *}$ & & & \\
\hline$L E V$ & $0.231^{* * *}$ & $0.139^{* * *}$ & $0.184^{* * *}$ & $-0.108^{* * *}$ & $-0.116^{* * *}$ & $0.187^{* * *}$ & & \\
\hline BETA & $0.174^{* * *}$ & $0.111^{* * *}$ & $0.144^{* * *}$ & $0.036^{*}$ & $0.040^{* *}$ & $0.158^{* * *}$ & $0.229^{* * *}$ & \\
\hline FOR & $-0.207^{* * *}$ & $-0.194^{* * *}$ & $0.106^{* * *}$ & $0.101^{* * *}$ & $0.069^{* * *}$ & $0.458^{* * *}$ & $-0.150^{* * *}$ & $-0.071^{* * *}$ \\
\hline \multicolumn{9}{|c|}{ Panel B. Firm samples with voluntary disclosure data $(\mathrm{N}=1,226)$} \\
\hline & VOLA & $V O L$ & COUNT & $A Q 1$ & $A Q 2$ & $S I Z E$ & $L E V$ & BETA \\
\hline$V O L$ & $0.726^{* * *}$ & & & & & & & \\
\hline COUNT & $0.104^{* * *}$ & 0.030 & & & & & & \\
\hline$A Q 1$ & $-0.145^{* * *}$ & $-0.105^{* * *}$ & $-0.069^{* *}$ & & & & & \\
\hline$A Q^{2}$ & $-0.138^{* * *}$ & $-0.067^{* * *}$ & $-0.069^{* * *}$ & $0.790^{* * *}$ & & & & \\
\hline SIZE & $-0.393^{* * *}$ & $-0.386^{* * *}$ & $0.095^{* * *}$ & $0.182^{* * *}$ & $0.162^{* * *}$ & & & \\
\hline$L E V$ & $0.241^{* * *}$ & $0.143^{* * *}$ & $0.205^{* * *}$ & $-0.094^{* * *}$ & $-0.120^{* * *}$ & $0.164^{* * *}$ & & \\
\hline BETA & $0.166^{* * *}$ & $0.085^{* * *}$ & $0.088^{* * *}$ & $0.050^{* * *}$ & $0.051^{* * *}$ & $0.204^{* * *}$ & $0.254^{* * *}$ & \\
\hline FOR & $-0.306^{* * *}$ & $-0.263^{* * *}$ & 0.013 & $0.131^{* * *}$ & $0.105^{* * *}$ & $0.511^{* * *}$ & $-0.184^{* * *}$ & $-0.089^{* * *}$ \\
\hline
\end{tabular}

1) Please refer to Table 3 for variable definitions.

2 ) $* * *, * *, *$ denote significance at the $1 \%, 5 \%$, and $10 \%$ levels, respectively (two-tailed).

\subsection{Multivariate Results}

Using models (1) and (2), we perform multivariate regression analyses to test whether voluntary disclosure is associated with information asymmetry. In Table 5, coefficients $\left(\beta_{1}\right)$ on VOLA and VOL are 0.265 and -0.298 , significantly positive $(+)$ at $1 \%$ and significantly negative (-) at 5\% respectively. Consistent with previous studies (Sohn et al. 2008; Shin and Lee 2014; Jung 2015), voluntary disclosure rather increases information asymmetry, confirming Hypothesis 1 . The result shows that firms with voluntary disclosure have larger return variability and less share turnover, implying that firms tend to disclose favorable and biased information to the outside. Thus, the risk of information from the uncertainty of business will be high and the information asymmetry will increase.

In Table 6 , only the coefficient $\left(\beta_{1}\right)$ on VOLA is significantly positive $(+)$ at $1 \%$, partially supporting Hypothesis 2 . The results for the control variables are generally consistent with our expectations. The coefficients of SIZE in the models (1) and (2) are significantly negative as expected. The coefficients on LEV and BETA in the model (1) are significantly positive at $1 \%$ respectively as expected. These results are consistent with Cho and Jo (2010), Shin and Park (2014) and Oh and Shin (2016).

Across models, $\mathrm{R}^{2}$ values range from approximately 46.14 to 58.27 percent. Additionally, the F-statistic is significant, suggesting that our use of the regression model is appropriate. 
Table 5. The effect of voluntary disclosure on information asymmetry (H1)

\begin{tabular}{|c|c|c|c|c|c|c|c|c|}
\hline \multicolumn{9}{|c|}{$V O L A_{i t}=\beta_{0}+\beta_{1} V D_{i t}+\beta_{2} S I Z E_{i t}+\beta_{3} L E V_{i t}+\beta_{4} B E T A_{i t}+\beta_{5} V O L_{i t}+\beta_{6} F O R_{i t}+\varepsilon_{i t}$} \\
\hline \multicolumn{9}{|c|}{$V O L_{i t}=\beta_{0}+\beta_{1} V D_{i t}+\beta_{2} S I Z E_{i t}+\beta_{3} L E V_{i t}+\beta_{4} B E T A_{i t}+\beta_{5} V O L A_{i t}+\beta_{6} F O R_{i t}+\varepsilon_{i t}$} \\
\hline \multirow{2}{*}{ Variables } & \multirow{2}{*}{$\begin{array}{l}\text { Predicted } \\
\text { Sign }\end{array}$} & \multicolumn{3}{|c|}{ Dependent Variable VOLA } & \multirow{2}{*}{$\begin{array}{l}\text { Predicted } \\
\text { Sign }\end{array}$} & \multicolumn{3}{|c|}{ Dependent Variable VOL } \\
\hline & & Coefficient & t-value & p-value & & Coefficient & t-value & p-value \\
\hline INTERCEPT & & $5.529^{* * * *}$ & 17.53 & $<.0001$ & & $2.487^{*}$ & 1.68 & 0.0939 \\
\hline$V D$ & $(+)$ & $0.265^{* * *}$ & 8.66 & $<.0001$ & $(-)$ & $-0.298^{* *}$ & -2.16 & 0.0307 \\
\hline SIZE & $(-)$ & $-0.144^{* * *}$ & -11.63 & $<.0001$ & $(+)$ & $-0.272^{* * *}$ & -4.85 & $<.0001$ \\
\hline$L E V$ & $(+)$ & $0.807^{* * *}$ & 10.8 & $<.0001$ & $(+)$ & -0.198 & -0.58 & 0.5603 \\
\hline BETA & $(+)$ & $0.177^{* * *}$ & 6.29 & $<.0001$ & $(-)$ & -0.002 & -0.01 & 0.9885 \\
\hline$V O L$ & $(+)$ & $0.139^{* * *}$ & 39.95 & $<.0001$ & & & & \\
\hline VOLA & & & & & $(+)$ & $2.751^{* * *}$ & 39.95 & $<.0001$ \\
\hline FOR & $(-)$ & 0.001 & 0.66 & 0.5087 & $(+)$ & 0.003 & 0.46 & 0.6452 \\
\hline$F-V A L U E$ & & \multicolumn{3}{|c|}{$464.23^{* * *}$} & & \multicolumn{3}{|c|}{$369.81^{* * *}$} \\
\hline$A D J R-S Q$ & & \multicolumn{3}{|c|}{$51.83 \%$} & & \multicolumn{3}{|c|}{$46.14 \%$} \\
\hline
\end{tabular}

1) Please refer to Table 3 for variable definitions.

2) $* * *, * *, *$ denote significance at the $1 \%, 5 \%$, and $10 \%$ levels, respectively (two-tailed).

Table 6. The effect of voluntary disclosure frequency on information asymmetry (H2)

\begin{tabular}{|c|c|c|c|c|c|c|c|c|}
\hline \multicolumn{9}{|c|}{$V O L A_{i t}=\beta_{0}+\beta_{1} \operatorname{COUNT}_{i t}+\beta_{2} \operatorname{SIZE}_{i t}+\beta_{3} L E V_{i t}+\beta_{4} B E T A_{i t}+\beta_{5} V O L_{i t}+\beta_{6} F O R_{i t}+\varepsilon_{i t}$} \\
\hline \multicolumn{9}{|c|}{$V O L_{i t}=\beta_{0}+\beta_{1} C_{O U N T} T_{i t}+\beta_{2} S I Z E_{i t}+\beta_{3} L E V_{i t}+\beta_{4} B_{E T A_{i t}}+\beta_{5} V O L A_{i t}+\beta_{6} F O R_{i t}+\varepsilon_{i t}$} \\
\hline \multirow{2}{*}{ Variables } & \multirow{2}{*}{$\begin{array}{l}\text { Predicted } \\
\text { Sign }\end{array}$} & \multicolumn{3}{|c|}{ Dependent Variable VOLA } & \multirow{2}{*}{$\begin{array}{l}\text { Predicted } \\
\text { Sign }\end{array}$} & \multicolumn{3}{|c|}{ Dependent Variable VOL } \\
\hline & & Coefficient & t-value & p-value & & Coefficient & t-value & p-value \\
\hline INTERCEPT & & $5.045^{* * *}$ & 12.290 & $<.0001$ & & $2.720^{* *}$ & 2.430 & 0.015 \\
\hline COUNT & $(+)$ & $0.024^{* * *}$ & 3.560 & 0.000 & $(-)$ & -0.027 & -1.580 & 0.114 \\
\hline SIZE & $(-)$ & $-0.127^{* * *}$ & -7.960 & $<.0001$ & $(+)$ & $-0.190^{* * *}$ & -4.550 & $<.0001$ \\
\hline$L E V$ & $(+)$ & $0.683^{* * *}$ & 6.820 & $<.0001$ & $(+)$ & 0.091 & 0.350 & 0.729 \\
\hline BETA & $(+)$ & $0.234^{* * *}$ & 5.780 & $<.0001$ & $(-)$ & -0.015 & -0.140 & 0.885 \\
\hline$V O L$ & $(+)$ & $0.252^{* * *}$ & 29.580 & $<.0001$ & & & & \\
\hline VOLA & & & & & $(+)$ & $1.667^{* * *}$ & 29.580 & $<.0001$ \\
\hline FOR & $(-)$ & 0.001 & -0.310 & 0.755 & $(+)$ & 0.002 & 0.410 & 0.683 \\
\hline$F-V A L U E$ & & \multicolumn{3}{|c|}{$284.5^{* * *}$} & & \multicolumn{3}{|c|}{$235.67^{* * *}$} \\
\hline$A D J R-S Q$ & & \multicolumn{3}{|c|}{$58.27 \%$} & & \multicolumn{3}{|c|}{$53.62 \%$} \\
\hline
\end{tabular}

1) Please refer to Table 3 for variable definitions.

2) $* * *, * *, *$ denote significance at the $1 \%, 5 \%$, and $10 \%$ levels, respectively (two-tailed).

In Table 7, the effect of accruals quality on the relationship between voluntary disclosure and information asymmetry is significantly negative (-) for VOLA. The coefficients $\left(\beta_{3}\right)$ on the interaction variables (VD*AQ1_DUM and VD*AQ2 DUM) are -0.098 and -0.146 , significantly negative $(-)$ at $5 \%$ and $1 \%$ respectively, implying that investors respond differently to voluntary disclosure with accruals quality.

Only VOL is significantly positive when accruals quality is measured by the Kothari model (2005). The coefficient ( $\left.\beta_{3}\right)$ on the interaction variable (VD*AQ2 DUM) is significantly positive $(+)$ at $5 \%$, implying that with high accruals quality, more voluntary disclosure lowers information asymmetry. Thus, accruals quality has a moderating effect on the relationship between voluntary disclosure and information asymmetry, confirming our hypothesis 3.

In Table 8, the effect of accruals quality on the relationship between voluntary disclosure frequency and information asymmetry shows a significantly positive $(+)$ relationship for VOL only. The coefficients $\left(\beta_{3}\right)$ on VD*AQ1_DUM and VD*AQ2 DUM) are 0.044 and 0.065 , significantly positive $(+)$ at $1 \%$ and $5 \%$ respectively, implyings that high accruals quality lowers the intensity of the relationship between voluntary disclosure and information asymmetry. Overall, Hypothesis 4 is partially confirmed. 
Table 7. The effect of accruals quality on the association between voluntary disclosure and information asymmetry (H3)

$V O L A_{i t}=\beta_{0}+\beta_{1} V D_{i t}+\beta_{2} A Q_{D U M_{i t}}+\beta_{3} V D_{i t} \times A Q_{D U M_{i t}}+\beta_{4} S I Z E_{i t}+\beta_{5} L E V_{i t}+\beta_{6}$ BETA $_{i t}+\beta_{7} V O L_{i t}$ $+\beta_{8} F O R_{i t}+\varepsilon_{i t}$

$V O L_{i t}=\beta_{0}+\beta_{1} V D_{i t}+\beta_{2} A Q_{D U M_{i t}}+\beta_{3} V D_{i t} \times A Q_{D U M_{i t}}+\beta_{4} S I Z E_{i t}+\beta_{5} L E V_{i t}+\beta_{6} B E T A_{i t}+\beta_{7} V O L A_{i t}$ $+\beta_{8} F O R_{i t}+\varepsilon_{i t}$

\begin{tabular}{|c|c|c|c|c|c|c|c|c|c|c|}
\hline \multirow{2}{*}{ Variables } & \multirow{2}{*}{$\begin{array}{c}\text { Predicte } \\
\text { d Sign }\end{array}$} & \multicolumn{4}{|c|}{ Dependent Variable VOLA } & \multirow{2}{*}{$\begin{array}{l}\text { Predicted } \\
\text { Sign }\end{array}$} & \multicolumn{4}{|c|}{ Dependent Variable VOL } \\
\hline & & Coefficient & t-value & Coefficient & t-value & & Coefficient & t-value & Coefficient & t-value \\
\hline INTERCEPT & & $3.780^{* * *}$ & 12.750 & $3.742^{* * *}$ & 12.630 & & $3.856^{* * *}$ & 5.040 & $3.969^{* * *}$ & 5.190 \\
\hline$V D$ & $(+)$ & $0.252^{* * *}$ & 6.340 & $0.280^{* * *}$ & 7.070 & $(-)$ & -0.150 & -1.490 & $-0.191^{*}$ & -1.900 \\
\hline$A Q 1 \_D U M$ & & 0.009 & 0.240 & & & & -0.056 & -0.640 & & \\
\hline$V D^{*} \bar{A} Q 1 \_D U M$ & $(-)$ & $-0.098^{* *}$ & -1.950 & & & $(+)$ & 0.142 & 1.120 & & \\
\hline$A Q 2 \_D U M$ & & & & 0.022 & 0.640 & & & & 0.009 & 0.100 \\
\hline$V D * A Q 2 \_D U M$ & $(-)$ & & & $-0.146^{* * *}$ & -2.900 & $(+)$ & & & $0.220^{* *}$ & 1.730 \\
\hline SIZE & $(-)$ & $-0.082^{* * *}$ & -7.090 & $-0.081^{* * *}$ & -6.990 & $(+)$ & $-0.238^{* * *}$ & -8.180 & $-0.244^{* * *}$ & -8.400 \\
\hline$L E V$ & $(+)$ & $0.586^{* * *}$ & 8.570 & $0.580^{* * *}$ & 8.470 & $(+)$ & 0.091 & 0.520 & 0.128 & 0.730 \\
\hline BETA & $(+)$ & $0.168^{* * *}$ & 6.000 & $0.168^{* * *}$ & 6.010 & $(-)$ & 0.053 & 0.750 & 0.047 & 0.660 \\
\hline$V O L$ & $(+)$ & $0.269^{* * *}$ & 46.620 & $0.270^{* * *}$ & 46.730 & & & & & \\
\hline VOLA & & & & & & $(+)$ & $1.703^{* * *}$ & 46.620 & $1.705^{* * *}$ & 46.730 \\
\hline FOR & $(-)$ & -0.001 & -0.550 & -0.001 & -0.570 & $(+)$ & 0.003 & 1.110 & 0.003 & 1.130 \\
\hline$F-V A L U E$ & & \multicolumn{2}{|c|}{$438.58^{* * *}$} & \multicolumn{2}{|c|}{$440.29^{* * *}$} & & \multicolumn{2}{|c|}{$398.08^{* * * *}$} & \multicolumn{2}{|c|}{$399.42^{* * *}$} \\
\hline$A D J \quad R-S Q$ & & \multicolumn{2}{|c|}{$57.64 \%$} & \multicolumn{2}{|c|}{57.73} & & \multicolumn{2}{|c|}{$55.25 \%$} & \multicolumn{2}{|c|}{55.33} \\
\hline
\end{tabular}

1) Please refer to Table 3 for variable definitions.

2) $* * *, * *, *$ denote significance at the $1 \%, 5 \%$, and $10 \%$ levels, respectively (two-tailed).

Table 8. The effect of accruals quality on the association between voluntary disclosure frequency and information asymmetry (H4)

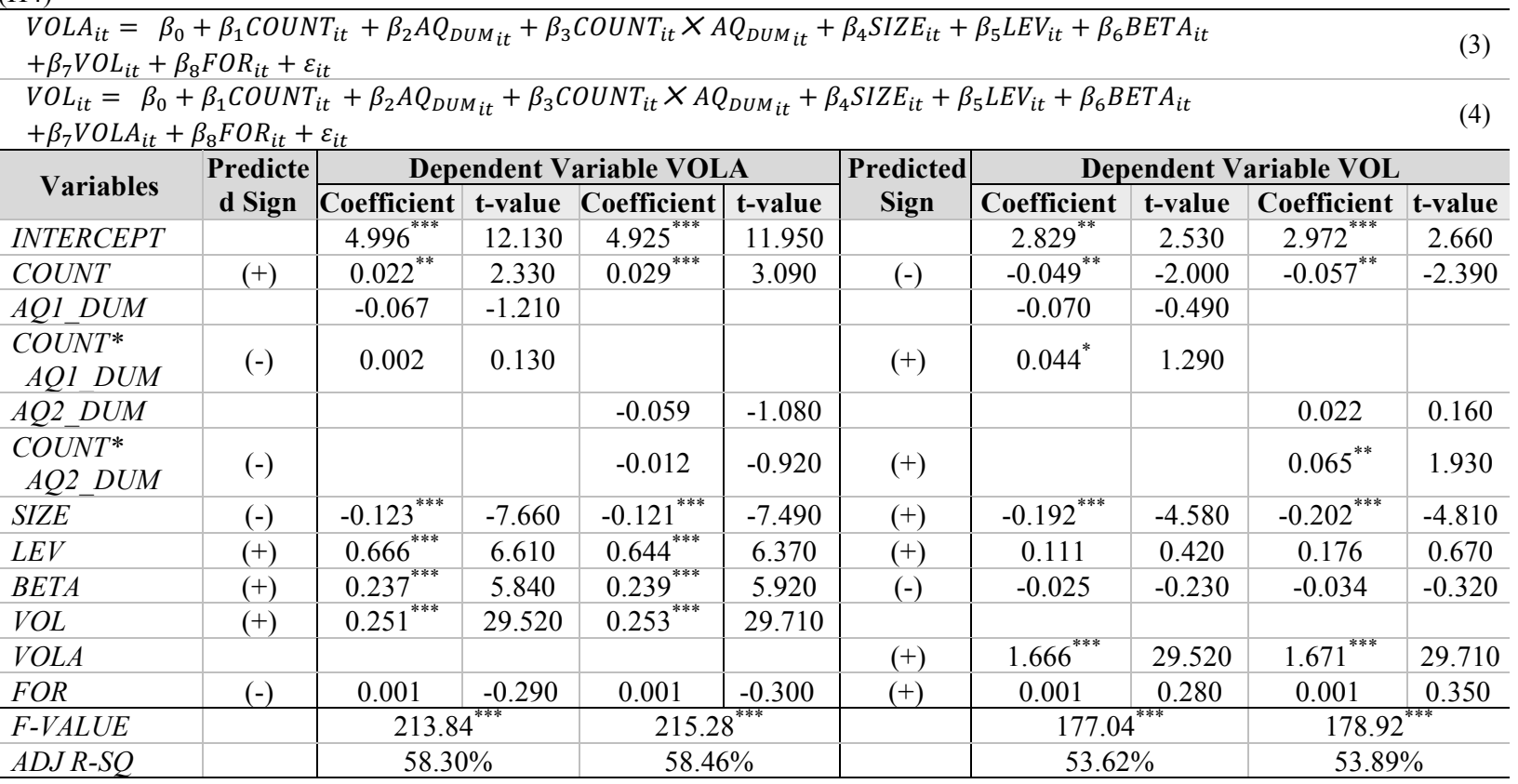

1) Please refer to Table 3 for variable definitions.

2) $* * * * *, *$ denote significance at the $1 \%, 5 \%$, and $10 \%$ levels, respectively (two-tailed).

\section{CONCLUSION}

We empirically examine the association between voluntary disclosure and information asymmetry and then investigate the extent to which this association is affected by accruals quality since Korea adopted International Financial Reporting Standards (IFRS) in 2011. 
The research findings generally support our hypotheses. First, the relation between voluntary disclosure and information asymmetry is statistically and significantly positive as we have expected. The Korean companies with high voluntary disclosure would experience higher daily stock return variability and less trading volume, which implies that companies tend to disclose biased information to the outside, which is consistent with prior studies in Korea. Second, the accruals quality (moderating variable) on the relation between voluntary disclosure and information asymmetry is statistically and significantly negative. Thus, we can conclude that when accruals quality is high, more voluntary disclosure decreases information asymmetry. These findings imply that accruals quality works as a mechanism in reducing the negative effect of voluntary disclosure on information asymmetry after the adoption of IFRS in Korea.

This study contributes to accounting research as it directly tests the effect of accruals quality on the relation between voluntary disclosure and information asymmetry in Korea, providing empirical evidence that accruals quality reduces the intensity of the relation between voluntary disclosure and information asymmetry. The results of this study imply that firms with more voluntary information enjoy reduced information asymmetry when the accruals quality is high.

The limitation of this study is such that we might not have considered other omitted variables and other proxies for the accruals quality, voluntary disclosure, and information asymmetry.

\section{AUTHOR BIOGRAPHIES}

Hoyoung Shin, Professor, School of Business, Hanyang University. She has been teaching at Hanyang University in South Korea since 1983. Her research focuses on the Disclosure, Information Asymmetry and Corporate Governance. Hoyoung Shin, Office 516, School of Business, Hanyang University, 222 Wangsimni-ro, Seongdong-gu, Seoul 04763, South Korea. E-mail: shinho@hanyang.ac.kr

Hyunmin Oh, Ph.D candidate, School of Business, Hanyang University. He has been majoring in Accounting to achieve doctoral degree at Hanyang University in South Korea since 2013. He received the Master of Accounting degree from Hanyang University. He also has been working at J Accounting Corporation since 2012. His research focuses on the Analysts, Earnings Management and Corporate Governance. Hyunmin Oh, Susan B/D, 3, Teheran-ro 6-gil, Gangnam-gu, Seoul, 135-934, South Korea. E-mail: gusals@hanyang.ac.kr (Corresponding author).

\section{REFERENCES}

Ahn, Y. Y., H. H. Shin, and J. H. Chang. (2005). The Relationship between the Foreign Investor And Information Asymmetry. The Korean Accounting Review 30 (4), 109-131.

Botosan, C. (1997). Disclosure Level and the Cost of Equity Capital. The Accounting Review 72 (3), 323-349.

Cho, J. S. and M. H. Jo. (2010). The Effect of Accrual Volatility on the Firms' Information Asymmetry, Forecast Error, and Cost of Capital. Korean Accounting Journal 19 (3), 175-199.

Cormier, D., and M. Magnan. (2002). Performance reporting by oil and gas firms: contractual and value implications. Journal of International Accounting, Auditing \& Taxation 11, 131-153.

Comprix, J., R. Graham, and J. Moore. (2011). Empirical evidence on the impact of book-tax differences on divergence of opinion among investors. Journal of the American Taxation Association 33(1), 51-78.

Dechow, P. M., R. G. Sloan, and A. P. Sweeney. (1995). Detecting Earnings Management. The Accounting Review 70, $193-225$.

Ecker, F., J. Francis., I. Kim., P. Olsson, and K. Schipper. (2006). A Return-based Representation of Earnings Quality. The Accounting Review 81(3), 749-780.

Francis, J., R. La Fond, P. Olsson, and K. Schipper. (2005). The Market Pricing of Accruals Quality. Journal of Accounting and Economics 39 (2), 295-327.

Francis, J., Nanda, D. and P. Olsson. (2008). Voluntary Disclosure, Earnings Quality, and Cost of Capital. Journal of Accounting Research. 46, 1-47.

Glosten, L. and P. Milgrom. (1985). Risk, Return and Equilibrium: Empirical Tests. Journal of Financial Economics. 13.

Jung, H. U. (2015). The Effect of Voluntary Disclosure Level on Foreign Equity Ownership. Korea International Accounting Review 59, 167-192.

Kim, O., and R. Verrecchia. (1991). Market Reactions to Anticipated Announcements. Journal of Financial Economics 30, 273309.

Kothari, S. P., A. J. Leone, and C. E. Wasley. (2005). Performance Matched Discretionary Accrual Measures. Journal of Accounting and Economics 39, 163-197. 
Lang, M., and R. Lundholm. (1993). Cross-sectional Determinants of Analyst Ratings of Corporate Disclosures. Journal of Accounting Research 31, 246-271.

Lee, M. Y. and H. Y. Shin. (2010). Voluntary Disclosure and Cost of Capital. Accounting Information Research 28(4), 163-186.

Leuz, C., and R. Verrecchia. (2000). The Economic Consequences of increased Disclosure. Journal of Accounting Research 38 (supplement), 91-124.

Oh, H. M. and H. Y. Shin., and S. W. Hong. (2016). Voluntary Disclosure, Information Asymmetry and Corporate Governance after the Adoption of IFRS. Accounting Information Research 34(2), 159-188.

Oh, H. M. and H. Y. Shin, and S. W. Hong. (2015). The Effect of Corporate Governance on the Association between Earnings Management and Firm Value. Global Business Administration Review 12(4), 77-106.

Rajgopal, S., and M. Venkatachalam. (2006). Information Risk and Idiosyncratic Return Volatility Over the Last Four Decades. Working paper, University of Washington and Duke University, 2006.

Shin, H. Y. and H. J. Park. (2014). The Effect of Financial Statement Comparability on Divergence of Opinion among Investors. The Korean Accounting Review 39 (2): 265-311.

Shin, H. Y. and S. I. LEE. (2014). The Effect of Corporate Governance on the Association between Voluntary Disclosure and Cost of Equity. Business Education Research 28 (3), 1-23.

Sohn, S. K., B. J. Kwak, and L. H. Jin. (2008). The Effect of Voluntary Disclosure on Analysts' Earning Forecasts. Accounting Information Research 26 (2), 1-26.

Verrecchia, R. (2001). Essays on Disclosure. Journal of Accounting and Economics 32, 97-180.

Watts, R. and J. Zimmerman. (1990). Positive Accounting Theory: A Ten Year Perspective. The Accounting Review 65 (1), 131-156. 